\title{
Sense of wonder
}

\section{Memories are made of this.}

\section{Richard A. Lovett}

Clay Nadir wanted a book for the beach. Not just any book, but the type that makes you forget the beach, other than as the place where you discovered Jack London or Sherlock Holmes or Norman Mailer. But even on the shelves of his city's largest bookstore, he wasn't finding anything. It was as though everything new had long ago been stuffed into his brain.

Maybe he was jaded. Maybe, once you'd worked your way through Agatha Christie, no manor house would ever again hold your attention. And was The Time Machine really that good, or had it simply been a first, both for Clay and the world?

Nature writing, westerns, mountaineering, ghost stories, dysfunctional families ... literarily, Clay had been there, done that. In the past hour he'd wandered though fantasy, mystery, biography and what a friend called 'Qual. Lit.' - a conceited term if ever there was one. Quality literature, ha! As though any genre had a monopoly. Not to mention that once you'd read Nabokov and Woolf and Joyce, you could get as jaded with that stuff as anything else. Even Shakespeare you could eventually memorize.

Maybe he should try romance. He'd never dabbled in it before, so at least it would be different.

Then, in the occult section, something caught his eye. It was an odd book: black, with a red, spiral vortex on the cover. It made him think of Hitchcock's Vertigo. Now that was a movie: Jimmy Stewart and Kim Novak in a deceptively simple story you had to see several times to fully grasp. But once you did, so many other movies seemed so ... trivial.

The book also made him think of something from his youth. Something to do with an old TV show. What was it called? Oh yes, The Time Tunnel. Each week, they'd spun this thing like a giant pinwheel and run off to some distant era. Probably unbelievably stupid if he watched it today, but at the time it hit him like his first viewing of Doctor Who, another show involving a time vortex, plus a lot of other things he'd never seen before.

There was no author listed, and as he picked up the book, he seemed to be falling into the vortex. On the back was a simple endorsement: 'Guaranteed to restore your sense of wonder'.
Yeah, right. He'd heard that one before.

He opened it but there was no preface, no introduction, no writing at all. Just more spirals, one to a page, these in blackand-white.

He nearly set it back down, but the sense of being sucked in was too strong. It was as though the entire room were spinning: just what Jimmy Stewart's character must have felt as he looked into the depths ... Dizzying enough that Clay no longer wanted to think about Stewart or Hitchcock or old TV shows.

There was a white circle in the centre of the first spiral.

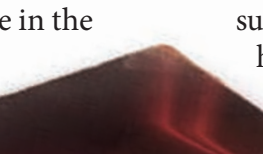

about whistling and moaning. Something about singing insects.

Then, it was over. Clay had no idea how long he'd been staring at the book. All he knew was that he'd flipped through most of the pages, but not all. He looked at the next few, but they were simply spirals. Still dizzying, but not like before. He flipped back, but there were no longer any words or images. Just paper.

There was no price tag on the book. Clay wondered briefly why it had been so captivating. Maybe he'd merely let his blood sugar dip too low. Maybe the spirals caught him off guard.

He put the book back where he'd found it, on a countertop beside a computer terminal where customers
Peering into it he saw flickers of motion: barely remembered images of Jimmy Stewart, Kim Novak and maybe The Time Tunnel.

With an effort, he turned the page. Another spiral, again sucking him in. This time, he saw words.

Call me Ishmael.

It was the best of times...

In the beginning God created the heavens and earth.

Once upon a time there was a Martian named Valentine Michael Smith.

To be, or not to be...

Rather than simply reading them, he felt as though the words were being pulled from him, faster and faster. He turned another page and another and another. It wasn't just words and videos. There were also stills: a stern-looking couple with a pitchfork; a woman with an odd half-smile. Guitar riffs, symphonies, something about Lucy in the sky with a yellow submarine. Names for these would tickle his memory then be gone, often faster than he could grasp what they had been. Something 